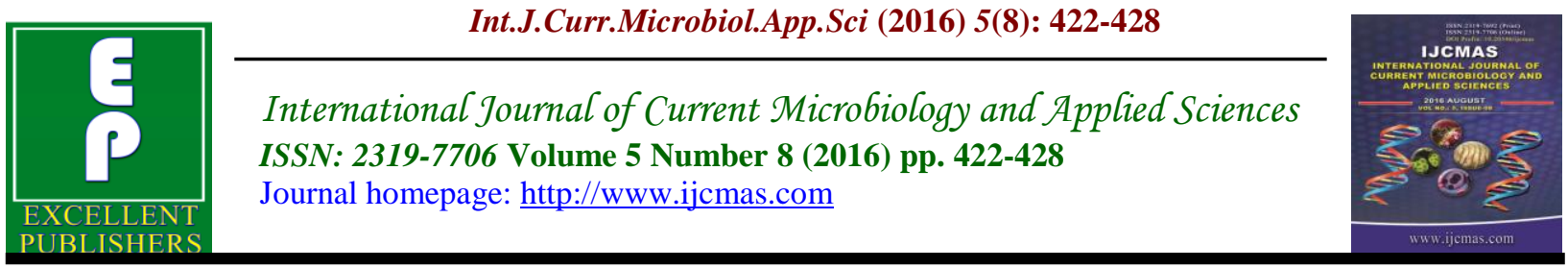

Original Research Article

http://dx.doi.org/10.20546/ijcmas.2016.508.045

\title{
The Effect of $\mathrm{CaO}$ on the Yield and Composition of Goat Bone Gelatin
}

\author{
Mustakim*, Hari Purnomo, Lilik Eka Radiati and Djalal Rosyidi \\ Animal Product Technology, Animal Husbandry Faculty, Brawijaya University, \\ Malang 65145, East Java, Indonesia \\ *Corresponding author
}

\begin{abstract}
A B S T R A C T
Keywords

$\mathrm{CaO}$ source, gelatin yield and proximat quality.

Article Info

Accepted:

21 July 2016

Available Online:

10 August 2016

Goat bone as by product of goat slaughterhouse are potential as the source of collagen protein was extracted to obtain gelatin. $\mathrm{CaO}$ is a chemical used in gelatin manufacturing from goat bone. The supply of goat bone in East Java Indonesia is over supply and continued. The purpose of this research were to find out the effect of $\mathrm{CaO}$ source on gelatin yields and proximate composition of goat bone gelatin, using Completely Randomized Design. The treatment was source of $\mathrm{CaO}$ from Tulungagung (A), Malang (B) and Tuban (C) region, each treatment are three replications. The result showed that $\mathrm{CaO}$ source did not gave significant effect ( $p>0.05)$ gelatin yields, however gave highly significant effect $(\mathrm{p}<0.01)$ on water, ash, protein and fat content of goat bone gelatin. The average of the yield was 12.00-15.65\%; water content 4.98-8.57\%; ash 2.27-4.55\%; protein 81.29-96.77\% and fat content $0.66-3,82 \%$. It concluded that $\mathrm{CaO}$ from Tulungagung, Malang dan Tuban region gave similar goat bone gelatin yields and quality as SNI (Indonesia National Standard).
\end{abstract}

\section{Introduction}

Gelatin is the protein obtained from hydrolysis of collagen (Karim and Bhat, 2009). It is mainly produced from bovine and porcine skin and demineralized bones (Killekar et al., 2011; Jamaludin, et al., 2012). The increasing demand of halal gelatin in Indonesia in food and nonfood industry especially for Muslims, therefore, the extraction of gelatin from alternative mammals, especially from bone goat as by product from goat slaughtering. Bone goat can be used as an alternative raw material for gelatin extraction. However, little information about gelatin from goat bone has been reported.
In gelatin production from goat bone, it need $\mathrm{CaO}$ to ossein swelling. $\mathrm{CaO}$ produced from limestone that naturally formed by organic, mechanical and chemically with magnesium, clay and sand as polluter. Therefore, $\mathrm{CaO}$ from different region has different mineral content (Jimson, 2012). $\mathrm{CaO}$ active and solubilize formed $\mathrm{Ca}(\mathrm{OH})_{2}$ and heat. $\mathrm{Ca}(\mathrm{OH})_{2}$ and water at $20-55 \%$ formed lime slurry with $\mathrm{pH} \pm 12,4$ (Anonymous, 2008).

Alkaline pretreatment (liming process) is particularly established for gelatin extraction from mammalian bones (Schrieber and 
Gareis, 2007). Alkaline solution plays an important role in breaking crosslinks in the skin matrixe stabilized by strong bonds, thereby increasing extraction efficiency (Ward and Courts, 1977). The purpose of ossein dipping in lime slurry is removing non-collagen component, the process takes several months (Schrieber and Gareis, 2007) for 35-75 days (Anonymous, 2002). The quality of gelatin may be attributed with ossein dipping process, especially in the composition and yields of gelatin.

This research purposed to investigate the effect of $\mathrm{CaO}$ pretreatment on the composition and yield of gelatin from bone goat obtained from a slaughterhouse in Malang Region, East Java Indonesia.

\section{Materials and Methods}

\section{Materials}

Bone of ettawa crossbreed goat from local market, $\mathrm{CaO}$ from Tulungagung, Malang and Tuban region, $\mathrm{HCl}$ (merck), $\mathrm{H}_{2} \mathrm{SO}_{4}$, Kjeldahl tablet, $\mathrm{H}_{3} \mathrm{BO}_{4}, \mathrm{BCG}$ indicator, petroleum eter

\section{Methods}

The method using Completely Randomized Design, the treatment was the source of $\mathrm{CaO}$ from Tulungagung, Malang and Tuban Region East Java Indonesia, each treatment are three replications. The variables were the yields, water, ash, protein and fat content of Goat Bone Gelatin.

Yield (Gimenez, et al., 2005)

Gelatin yield was calculated by the following equation

Yield $(\%)=\frac{\text { b }}{\text { a }}$

Where: $\mathrm{a}=$ weight of initial dry goat bone (g)

$$
\mathrm{b}=\text { weight of dry gelatin }(\mathrm{g})
$$

\section{Water content (Anonymous, 2011)}

Dry empty dish and lid in the oven at $105^{\circ} \mathrm{C}$ for $3 \mathrm{~h}$ and transferred to desiccators to cool. Weight the dish and lid. Weight about $2 \mathrm{~g}$ of sample to the dish and place the dish with sample in the oven, dry for $24 \mathrm{~h}$ at $105^{\circ} \mathrm{C}$. After drying, transfer the dish to the desiccators to cool. Reweight the dish and its dried sample.

Water content $(\%)=\frac{\text { W1-W2 }}{\text { W1 }}$

Where: $\mathrm{W} 1$ = weight sample before drying $(g)$

drying $(g)$

$$
\mathrm{W} 2 \text { = weight sample after }
$$

\section{Ash content (Anonymous, 2011)}

Place the crucible and lid in the furnace at $550^{\circ} \mathrm{C}$ overnight to ensure that impurities at surface of crucible are burned off. Cool the crucible in the desiccators (30 minutes). Weigh the crucible and lid. Weigh about $5 \mathrm{~g}$ sample into the crucible. Heat at $550^{\circ} \mathrm{C}$ overnight. Cooldown in the desiccators. Weigh the ash and crucible and lid if the sample turns to gray. If not, return the crucible and lid to the furnace for the further ashing.

$$
\begin{aligned}
& \text { Ash content }(\%)=\text {--------------------- } x \\
& 100
\end{aligned}
$$

$$
\text { Weight of sample }
$$

\section{Protein content (Anonymous, 2011)}

Determination of protein content using AOAC method 38.1.01 D involed 3 steps, 
destruction, distillation and titration. The destruction using Kjeltec 2200 FOSS, 1 g sample + bussino tablet + $12 \mathrm{ml} \mathrm{H}_{2} \mathrm{SO}_{4}$ was heated in the FOSS tube at $\pm 410^{\circ} \mathrm{C}$ for 60 min. The results of destruction in FOSS tube was distilled with thio- $\mathrm{NaOH} 40 \%, \mathrm{H} 3 \mathrm{BO} 4$ 4\%, BCGMR indicators in Kjeltec FOSS Destilator for $4 \mathrm{~min}$ to obtain $150 \mathrm{ml}$ of destilate. The Destilate in Erlenmeyer flask was titrated with $0.1 \mathrm{~N} \mathrm{HCl}$ until the color changed from blue to pink. The conversion factor of gelatin protein was 5.55, The protein content $(\%)$ was calculated using the formula

Protein content $(\%)=$

(ml $\mathrm{HCl}$ sample-ml HCl Blanko) x N HCl x 14.008 x $100 \times 5.55$

g sample x 1000

\section{Fat content (Anonymous, 2011)}

Determination of fat content using AOAC, 39.1.08 method, $3 \mathrm{~g}$ of dried sample filled to dried extraction thimble. The thimbles plus sample were extracted in a Soxhlet apparatus for $3 \mathrm{~h}$ using petroleum ether. The soxhlet tube containing petroleum eter was dried in the oven at $105^{\circ} \mathrm{C}$ for $1 \mathrm{~h}$. Dried sample was inserted in a desiccator for 30 minutes. Weights the dried extracted samples were determined using the formula

$$
\text { Fat Content }(\%)=\frac{\text { g Fat }}{\text { g Sample }}
$$

\section{Result and Discussion}

\section{Gelatin yield}

$\mathrm{CaO}$ source did not gave significant effect $(p \geq 0,05)$ on the yield of goat bone gelatin. Dipping in $\mathrm{CaO}$ solution from Tulungagung and Malang Region did not gave significant effect $(p \geq 0,05)$ on the yield of goat bone gelatin, however Dipping in $\mathrm{CaO}$ solution from Tuban gave highly significant effect $(p \leq 0,01)$ on the yield of goat bone gelatin as presented at Figure 1.

Highest gelatin yield of goat bone gelatin produced from ossein that dipped in $\mathrm{CaO}$ solution from Malang (14.69\%), which produced from ossein that dipped in $\mathrm{CaO}$ solution from Tulungagung (13.21\%), and the lowest gelatin yield of goat bone gelatin produced from ossein that dipped in $\mathrm{CaO}$ solution from Tuban (12.69\%). The yield of goat bone gelatin may be attributed with $\mathrm{P}$ cotent of $\mathrm{CaO}$ solution, $\mathrm{P}$ content in $\mathrm{CaO}$ solution from Tulungagung and Malang was similar caused similar yields and higher than yield of goat bone gelatin that dipped in $\mathrm{CaO}$ from Tuban that containing higher $\mathrm{P}$ content in $\mathrm{CaO}$ solution. $\mathrm{P}$ content in $\mathrm{CaO}$ solution may be form phosphate acid and increase degradation on ossein protein caused higher solubilization of ossein layers that decreased the yield of goat bone gelatin.

\section{Water content}

Water content of food is interesting to know its effect on appearance, texture, flavor and acceptance, freshness and self life of food (Winarno, 1997). Water in a food affect microbial metabolism, enzyme activity, chemical reaction, enzymatic or nonenzymatic reaction that decrease nutritive value and organoleptic properties (Syarif dan Halid, 1993).

$\mathrm{CaO}$ source gave highly significant effect $(p \leq 0,05)$ on water content of goat bone gelatin. Lowest water content of goat bone gelatin produced from ossein that dipped in $\mathrm{CaO}$ solution from Tubah region $(5.87 \%)$, $\mathrm{CaO}$ from Tulungagung produced $6.08 \%$ and the higest obtained from ossein that dipped in $\mathrm{CaO}$ solution from Malang $(6.64 \%)$. It may be due to mineral content 
especially in $\mathrm{P}$ content, $\mathrm{CaO}$ from Malang lesser than $\mathrm{CaO}$ from Tulungagung and Tuban.

\section{Ash content}

$\mathrm{CaO}$ source gave highly significant effect $(p \leq 0.01)$ on ash content of goat bone gelatin. Highest ash content of goat bone gelatin produced from ossein that dipped in $\mathrm{CaO}$ solution from Malang (3.51\%), ossein that dipped in $\mathrm{CaO}$ from Tuban produced ash content $3.46 \%$, and lowest ash content of goat bone gelatin produced from ossein that dipped in $\mathrm{CaO}$ solution from Tulungagung $(3.26 \%)$, It may be due calcium content in $\mathrm{CaO}$ solution, calcium content of $\mathrm{CaO}$ were $730.77,728.75$ and $726.84 \mathrm{ppm}$ from Malang, Tulungagung and Tuban respectively. Higher $\mathrm{Ca}$ content in $\mathrm{CaO}$ from Malang produced higher as content than $\mathrm{CaO}$ from Tulungagung and Malang.

Fig.1 Gelatin yields of goat bone gelatin

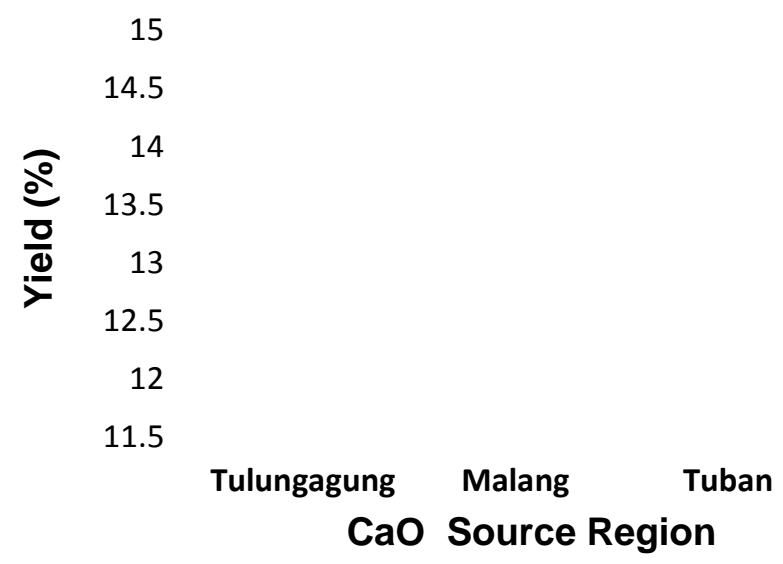

Fig.2 Water content of goat bone gelatin

6.8

6.6

6.4

6.2

6

5.8

5.6

5.4

Tulungagung Malang Tuban

CaO Source Region 
Fig.3 Ash content of goat bone gelatin

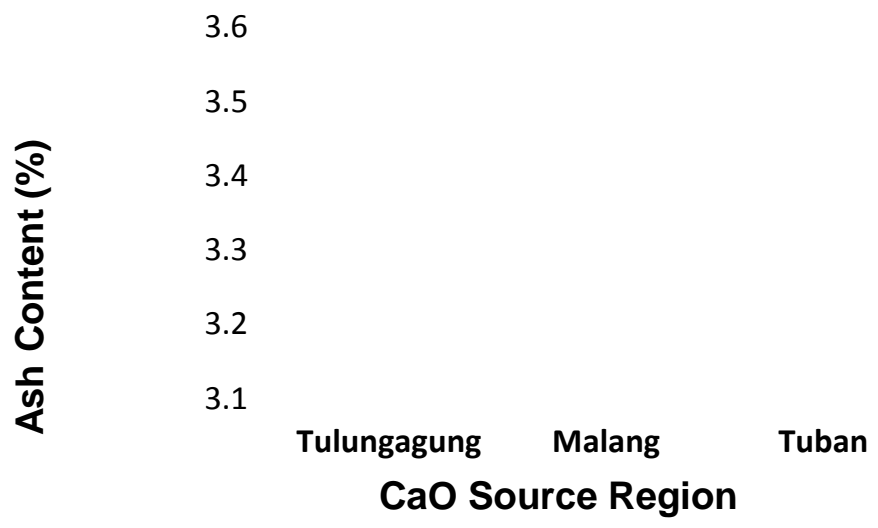

Fig.4 Protein content of goat bone gelatin

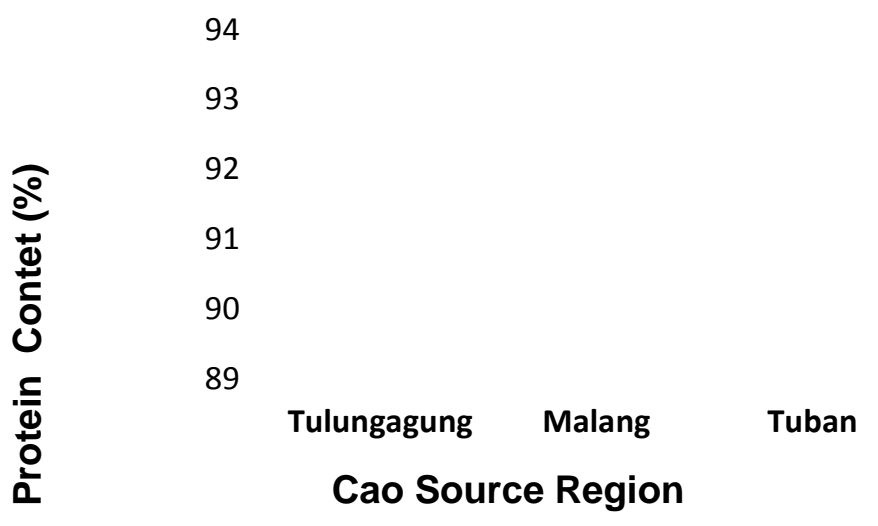

Fig.5 Fat content of goat bone gelatin

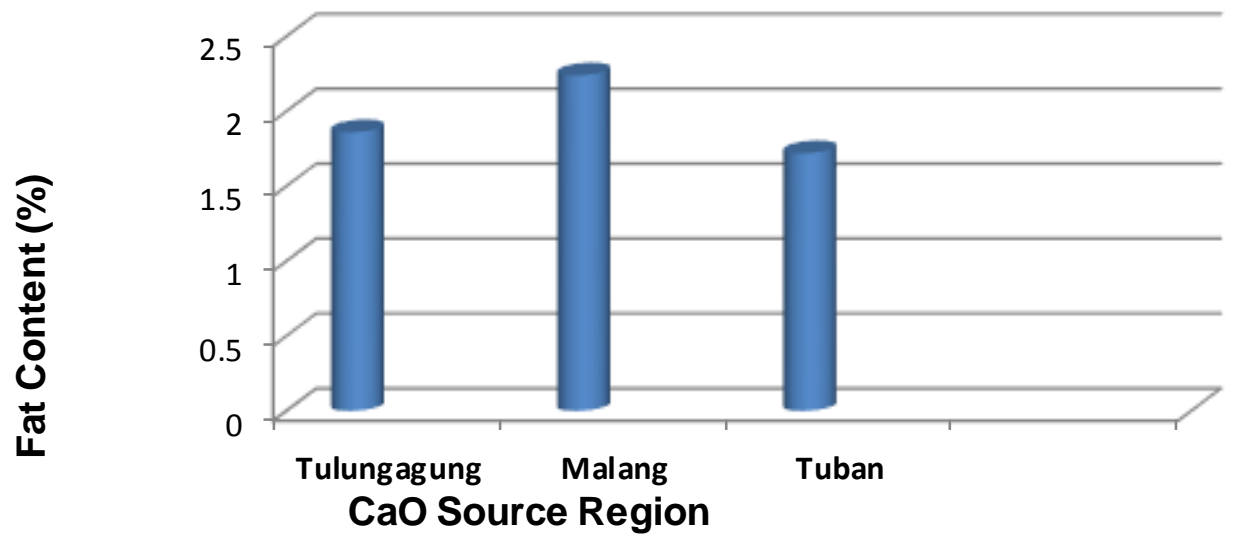




\section{Protein content}

Gelatin is pure protein produced from skin, bone or other organ. Protein content of gelatin can obtained 99\% (Anonymous, $2002^{\mathrm{a}}$ ). It obtained from collagen of extracellular matrix (Karim and Bhat, 2009) and applied as food additive in food product (Gomez, et al., 2011).

$\mathrm{CaO}$ source gave highly significant effect $(p \leq 0.01)$ on protein content of goat bone gelatin. Lowest protein content produced from ossein that dipped in $\mathrm{CaO}$ solution from Malang $(91,09 \%)$, ossein that dipped in $\mathrm{CaO}$ solution from Tuban produced protein content $92.97 \%$, highest protein content produced from ossein that dipped in $\mathrm{CaO}$ solution from Tulungagung $(93.53 \%)$

Ossein is bone that separated from mineral, mineral can separated from the bone using bone dipping in $5 \% \mathrm{HCl}$ solution for 72 hours. Physical properties of ossein softer than the bone, if it diiped in alkaline solution caused ossein swelling. Before protein ossein extraction become gelatin, it dipped in alkaline solution al least at $\mathrm{pH} 12.0$. It can dipped in $1-4 \% \mathrm{Ca}(\mathrm{OH})_{2}$ solution at $\mathrm{pH}$ 12.0-12.7 for 35-70 days (Anonymous, 2002). Ossein that dipped in $\mathrm{CaO}$ solution will changes, it signed as swelling. Ossein swelling is one of sign of "destruction" processed.

Higher $\mathrm{pH}$ of dipping alkaline solution caused higher "destruction", $\mathrm{OH}$ group caused destruction of hydrogen, covalent and peptide bond in ossein prodeuced lower molecular weight of protein (Ward and Court, 1977; Ofori, 1999). CaO solution used for ossein dipping was lime slurry, every week using new lime slurry, everyday it homogenized fol 5 minutes to keeping the $\mathrm{pH}$ stabilization of solution during dipping period (Anonymous, 2008).

\section{Fat content}

The quality of gelatin is affected by fat content, lowest fat content of gelatin is higher quality of gelatin. Fat color is yellowish, good taste because it containing provitamin A.

$\mathrm{CaO}$ source gave highly significant effect $(p \leq 0,05)$ on fat content of goat bone gelatin. Lowest fat content obtained from ossen dipped in $\mathrm{CaO}$ solution from Tuban $(1.72 \%)$, ossein that dipped in $\mathrm{CaO}$ solution from Tulungagung produced fat content $1.86 \%$, and higher fat content obtained from ossen dipped in $\mathrm{CaO}$ solution from Malang $(2.24 \%)$. Fat content have negative correlated with $\mathrm{P}$ content of $\mathrm{CaO}$ as curing agent. Higher $\mathrm{P}$ content in $\mathrm{CaO}$ used in ossein dipping produced lower fat content of gelatin. It may be attributed with $\mathrm{P}$ content in $\mathrm{CaO}$ solution which increase ossein fat degradation, produced lower fat content of gelatin.

It concluded that the source of $\mathrm{CaO}$ from Tulungagung, Malang and Tuban region convenion used in goat bone gelatin manufacturing and produced similar quality of goat bone gelatin. However, $\mathrm{CaO}$ source from Malang region gave the best result of goat bone gelatin.

\section{References}

Anonymous. 2002. WIPO. Gelatin Manufacturing Process and Product. File:///D:/gelatin/(WO-2002-072723).

Anonymous. 2008. BOC. Calcium Hydroxide (Lime Slurry). Priestly Road, Worsley, Manchester M28 2UT. Anonymous. 2011. Official Methods of Analisys of AOAC International, $18^{\text {th }}$ Edition. Washington.

Gimenez, B., M.C. Gomes-Guillen dan P. Montero. 2005. Storage of Dried Fish Skins on Quality Characteristics of Extracted Gelatin. Food 
Hydrocolloids, 19: (6) 958-963.

Jamaludin, M.A., M.A. Ramli, D.M. Hashim, and S.A. Rahman. 2012. Fiqh Istihalah : Integration of Science and Islamic Law. Revelation and Sci., 2(2): 117-123.

Jimson. 2012. Batu Gamping di Geologi Pertambangan (http://jimson. heck.in /batu-gamping.xhtml)

Karim, A.A. and R. Bhat. 2009. Fish Gelattin: Properties, Challenges and Prospects as an Alternative to Mammalian Gelatins. Food Hydrocolloid, 23: 563-576.
Killekar, V.C., J.M. Koli, S.T., Sharangdhar and Metar, S.Y. 2012. Functional Properties of Gelatin Extracted from Skin of Black Kingfish (Ranchycentron canadus). JLS, 2(3): 106-116.

Schrieber, R., H. Gareis. 2007. Gelatine Handbook, Theory and Industrial Practise. Maceration. Pp.66-69. WILEY-VCH VerlagGmbh \& Co. KgaA, Weinheim. Germany.

Ward, A.G. and A. Courts. 1977. The Science and Technology of Gelatin. Academic Press. London.

\section{How to cite this article:}

Mustakim, Hari Purnomo, Lilik Eka Radiati and Djalal Rosyidi. 2016. The Effect of CaO on the Yield and Composition of Goat Bone Gelatin. Int.J.Curr.Microbiol.App.Sci. 5(8): 422-428. doi: http://dx.doi.org/10.20546/ijcmas.2016.508.045 